\title{
Clinical Relevance of Serum HER2 and Circulating Tumor Cell Detection in Metastatic Breast Cancer Patients
}

\author{
MALGORZATA BANYS-PALUCHOWSKI ${ }^{1}$, ISABELL WITZEL ${ }^{2}$, SABINE RIETHDORF $^{3}$, BRIGITTE RACK $^{4}$, \\ WOLFGANG JANNI $^{5}$, PETER ANDREAS FASCHING ${ }^{6}$, ERICH-FRANZ SOLOMAYER ${ }^{7}$, BAHRIYE AKTAS $^{8}$, \\ SABINE KASIMIR-BAUER ${ }^{8}$, KLAUS PANTEL $^{3}$, TANJA FEHM ${ }^{9}$ and VOLKMAR MÜLLER ${ }^{2}$ \\ ${ }^{1}$ Department of Gynecology and Obstetrics, Marienkrankenhaus Hamburg, Hamburg, Germany; \\ ${ }^{2}$ Department of Gynecology, University Medical Center Hamburg-Eppendorf, Hamburg, Germany; \\ ${ }^{3}$ Department of Tumor Biology, University Medical Center Hamburg-Eppendorf, Hamburg, Germany; \\ ${ }^{4}$ Department of Gynecology and Obstetrics, Ludwig-Maximilian-University Munich, Munich, Germany; \\ ${ }^{5}$ Department of Gynecology and Obstetrics, University Hospital Ulm, Ulm, Germany; \\ ${ }^{6}$ Department of Gynecology and Obstetrics, Erlangen University, Erlangen, Germany; \\ ${ }^{7}$ Department of Gynecology and Obstetrics, Saarland University Hospital, Homburg/Saar, Germany; \\ ${ }^{8}$ Department of Obstetrics and Gynecology, University Hospital Essen, \\ University of Duisburg-Essen, Essen, Germany; \\ ${ }^{9}$ Department of Obstetrics and Gynecology, Heinrich-Heine-University Dusseldorf, Dusseldorf, Germany
}

\begin{abstract}
Background/Aim: Presence of circulating tumor cells (CTCs) is associated with impaired survival in metastatic breast cancer (MBC). This study was designed to evaluate whether assessment of serum HER2 (sHER2) levels provide additional prognostic information in MBC. Materials and Methods: Two hundred and fifty-three MBC patients were enrolled in this multicentre trial. CTCs were detected before the start of first- or later-line treatment using the CellSearch system. sHER2 was determined using ELISA. Results: $\geq 5$ CTCs were detected in 122 of 245 evaluable patients (49.8\%). One hundred and nineteen of 251 patients (47\%) had sHER2 levels above $15 \mathrm{ng} / \mathrm{ml}$. Median overall survival (OS) was 16.3 months in patients with elevated sHER2; median OS in patients with non-elevated sHER2 has not been reached $(p=0.001)$. Patients with $\geq 5$ CTCs were more likely to present with elevated sHER2 (61\% vs. $33 \%$ in those with $<5$ CTC; $p<0.001)$. In patients with HER2negative tumors, elevated sHER2 was associated with
\end{abstract}

This study was conducted on behalf of the DETECT Study Group.

Correspondence to: Prof. Tanja Fehm, Department of Obstetrics and Gynecology, Heinrich-Heine-University Dusseldorf, Moorenstr. 5, 40225 Dusseldorf, Germany. Tel: +49 2118117500, e-mail: tanja.fehm@med.uni-duesseldorf.de

Key Words: Breast cancer, circulating tumor cell, serum HER2, prognosis, survival, biomarker. shorter OS and PFS; in HER2-positive patients with OS only. Including sHER2, CTC status and established prognostic factors into a multivariate analysis, only the presence of CTCs and higher-line of therapy remained independent predictors of OS. Conclusion: Elevated levels of sHER2 are associated with worse survival, irrespective of the HER2 status of the tumor. However, sHER2 does not provide additional prognostic information in patients with known CTC status.

Hematogenous spread of single cancer cells that broke free from the primary tumor is an essential step in the metastatic cascade (1). These cells enter the blood circulation and may persist in their secondary homing sites where they interact through complex mechanisms with the microenvironment. As putative precursors of metastatic growth, circulating tumor cells (CTCs) can be detected in most solid tumors of epithelial origin, but no entity has been studied in this context as extensively as breast cancer (BC). Numerous studies have confirmed the presence of CTCs as an independent prognostic factor in metastatic $\mathrm{BC}$, with an established cut-off of five or more tumor cells per $7.5 \mathrm{ml}$ of peripheral blood $(2,3)$. Since metastatic cancer is a dynamic and heterogeneous disease, its features, particularly with regard to predictive markers, may change over time. Evaluation of CTCs and their expression profiles may therefore improve our understanding of the current status of the disease and serve as a 'liquid biopsy'. 
One of the most important prognostic and predictive factors in $\mathrm{BC}$ is the overexpression of the human epidermal growth factor receptor 2 (HER2). The current guidelines define a primary tumor as HER2-positive if more than $10 \%$ of the cells show a strong staining by immunohistochemistry or if a specific cut-off is reached on in situ hybridisation. While this definition has been confirmed in multiple trials, one has to bear in mind that tumors as well as different metastatic sites are heterogeneous in nature, and those considered HER2negative by these criteria may consist of HER2-positive cells as well. HER2 receptor seems to provide these cells with higher metastatic potential and thus with a survival advantage; indeed, the HER2 status of tumor cells encountered in blood or bone marrow differs from primary tumor in a significant proportion of patients (4-6).

The HER2 protein contains three domains, of which the extracellular one can be released into the blood after being cleaved from the cell surface by metalloproteases. The possibility of measuring levels of circulating HER2 in the serum has gained considerable interest in the past two decades. While this strategy has not been implemented into clinical routine, several studies have shown that elevated serum HER2 (sHER2) levels are associated with impaired survival and response to treatment (7-11). Furthermore, since patients with HER2-negative primary tumors frequently present with elevated sHER2 levels, sHER2 testing might potentially identify a subgroup that might derive benefit from anti-HER2 directed therapies $(12,13)$.

The aim of the present study was to evaluate sHER2 levels and the presence of CTCs in patients with metastatic breast cancer and assess the association of these markers with clinical outcome.

\section{Materials and Methods}

A total of 253 patients with metastatic breast cancer from nine German Breast Cancer Centres were enrolled in this prospective, multicentre, open-label, non-randomized study. All patients were diagnosed with metastatic epithelial breast carcinoma. Further inclusion criteria were: age 18 years and older, and first diagnosis of metastatic disease or disease progression before start of a new treatment line. Patients with a second primary malignancy (except in situ carcinoma of the cervix or adequately treated cutaneous basal cell carcinoma) were excluded. Blood samples were collected before start of a new line of therapy chosen according to national and institutional standards. Response to therapy was evaluated by computed tomography every 12 weeks. Informed consent was obtained from all individual participants included in the study.

Detection of circulating tumor cells. CTCs were detected using the CellSearch $^{\mathrm{TM}}$ system (Veridex LLC, NJ, USA). Briefly, $7.5 \mathrm{ml}$ peripheral blood was collected into CellSave Tubes and processed according to manufacturer's instructions. The assay consisted of an immunomagnetic enrichment step employing immunomagnetic beads coated with anti-epithelial cell adhesion molecule (EpCAM) antibody, followed by staining with several antibodies. A circulating tumor cell is defined as a CD45-negative cytokeratin-positive cell with a DAPI-stained nucleus. In the current study, CTC-positive patients were defined as those with at least five tumor cells per 7.5 $\mathrm{ml}$ blood.

Characterization of HER2 status of CTCs. HER2 expression of CTCs was characterized within the CellSearch assay by addition of a fluorescein isothiocyanate-labeled anti-HER2 antibody (Veridex LLC, NJ, USA), as described previously (6). To evaluate the intensity of HER2 immunostaining, approximately 500 breast cancer cells from cell lines with known HER2 status (MCF-7: no HER2 gene amplification, MDA-MB-453: 2- to 3-fold HER2 gene amplification, SK-BR-3 and BT474: 5- to 7-fold HER2 gene amplification) were spiked into $7.5 \mathrm{ml}$ blood from healthy donors and were processed under identical conditions with the CellSearch assay. The intensity of the HER2-specific immunofluorescence was categorized into negative $(0)$, weak (1+), moderate (2+), and strong (3+). CTCs were considered HER2-positive if at least one CTC had strong HER2 staining (3+) based on the cut-off level described previously (14).

Detection of serum HER2. sHER2 was determined using a commercially available enzyme-linked immunosorbent assay (ELISA) (Martell Diagnostic Laboratories, Roseville, MN, USA; formerly Wilex Inc, Cambridge, MA, USA), as described previously (11). This test is based on the quantitative measurement of the extracellular domain of the HER2 protein. Briefly, the assay uses one mouse monoclonal antibody to capture the extracellular domain and another one to detect and quantify it, and has been cleared by the Food \& Drug Administration (FDA) with the recommended cutoff of $15 \mathrm{ng} / \mathrm{ml}(15-17)$.

Statistical analysis. Chi-squared test and Fisher's exact test were used to evaluate the relationship between CTC and sHER2 detection and clinicopathological factors. For the survival analysis, we considered in separate analyses the following primary end points: 1) death and 2) progression. Survival intervals were measured from the time of blood sampling to the time of death or of the first clinical, histological or radiographic diagnosis of progression. We constructed Kaplan-Meier curves and used the log-rank test to assess the univariate significance of the parameters. Cox regression analysis was used for multivariate analysis. All reported $p$-values are two-sided. Statistical analysis was performed by SPSS, version 18 (SPSS Inc., Chicago, IL, USA). The analysis was performed according to the REporting recommendations for tumor MARKer prognostic studies (REMARK) criteria on reporting of biomarkers (18). The primary question was the prognostic impact of sHER 2 and CTC in the entire patient cohort.

Ethical approval. All procedures performed in this study were in accordance with the ethical standard of the institutional and national research committee and with the 1964 Helsinki declaration and its later amendments or comparable ethical standards. The study was approved by the local ethical committees of participation institutions.

Informed consent. Informed consent was obtained from all individual participants included in this study. 
Table I. Patients' characteristics (significant values are shown in bold).

\begin{tabular}{|c|c|c|c|c|c|c|}
\hline & \multicolumn{3}{|c|}{ Serum HER } & \multicolumn{3}{|c|}{ CTC status } \\
\hline & Total & $\begin{array}{c}\text { sHER2 elevated } \\
\mathrm{n}(\%)\end{array}$ & $p$-Value & Total & $\begin{array}{c}\geq 5 \mathrm{CTCs} / 7.5 \mathrm{ml} \\
\mathrm{n}(\%)\end{array}$ & $p$-Value \\
\hline Overall & 251 & $119(47 \%)$ & & 245 & $122(50 \%)$ & \\
\hline ER status & & & 0.616 & & & 0.265 \\
\hline Negative & 76 & $38(50 \%)$ & & 74 & $33(45 \%)$ & \\
\hline Positive & 174 & $81(47 \%)$ & & 170 & $89(52 \%)$ & \\
\hline PR status & & & 0.252 & & & 0.514 \\
\hline Negative & 102 & $53(52 \%)$ & & 99 & $47(48 \%)$ & \\
\hline Positive & 148 & $66(45 \%)$ & & 145 & $75(52 \%)$ & \\
\hline HER2 status & & & $<0.001^{4}$ & & & $0.055^{4}$ \\
\hline Negative $^{1}$ & 143 & $55(38 \%)$ & & 138 & $76(55 \%)$ & \\
\hline Positive $^{2}$ & 75 & $49(65 \%)$ & & 75 & $31(41 \%)$ & \\
\hline Unknown 3 & 33 & $15(45 \%)$ & & 32 & $15(47 \%)$ & \\
\hline Metastatic site & & & 0.030 & & & 0.007 \\
\hline Visceral & 99 & $49(49 \%)$ & & 96 & $39(41 \%)$ & \\
\hline Bone & 34 & $9(26 \%)$ & & 35 & $14(40 \%)$ & \\
\hline Both & 118 & $61(52 \%)$ & & 114 & $69(61 \%)$ & \\
\hline Extent of metastatic disease & & & 0.004 & & & 0.035 \\
\hline One site & 84 & $29(34 \%)$ & & 84 & $34(41 \%)$ & \\
\hline Multiple sites & 167 & $90(54 \%)$ & & 161 & $88(55 \%)$ & \\
\hline Therapeutic setting & & & 0.092 & & & 0.482 \\
\hline 1st-line & 96 & $38(40 \%)$ & & 94 & $48(51 \%)$ & \\
\hline 2nd-line & 66 & $31(47 \%)$ & & 64 & $28(44 \%)$ & \\
\hline 3rd-line or more & 88 & $49(56 \%)$ & & 86 & $46(545)$ & \\
\hline Grading & & & 0.592 & & & 0.679 \\
\hline G1 & 6 & $2(33 \%)$ & & 6 & $2(33 \%)$ & \\
\hline $\mathrm{G} 2$ & 128 & $60(37 \%)$ & & 123 & $63(51 \%)$ & \\
\hline G3 & 103 & $53(51 \%)$ & & 102 & $50(49 \%)$ & \\
\hline $\mathrm{CTCs}^{5}$ & & & $<0.001$ & & & \\
\hline$<5 \mathrm{CTCs} / 7.5 \mathrm{ml}$ & 122 & $40(33 \%)$ & & & & \\
\hline$\geq 5 \mathrm{CTCs} / 7.5 \mathrm{ml}$ & 121 & $74(61 \%)$ & & & & \\
\hline HER2 status of CTCs & & & 0.035 & & & \\
\hline Positive & 56 & $35(62 \%)$ & & & & \\
\hline Negative & 123 & $56(45 \%)$ & & & & \\
\hline
\end{tabular}

${ }^{1}$ IHC score: $0 /+1$ or FISH negative; ${ }^{2}$ ICH score: +3 or FISH positive; ${ }^{3}$ not determined or ICH score +2 and FISH not performed; ${ }^{4}$ Analysis performed only in patients with known HER2 status; 5 in 8 patients CTC status could not be determined.

\section{Results}

Patients' characteristics and CTC detection. Two hundred and fifty-three patients diagnosed with metastatic breast cancer were included into the analysis. Clinical-pathological data are summarized in Table I. Median age of all patients was 60 years. $39 \%$ of patients were included into the study before start of first-line therapy. HER2 was overexpressed by the primary tumor and/or metastasis in $35 \%$ of patients. Five or more CTCs per $7.5 \mathrm{ml}$ of peripheral blood were detected in 122 of 245 evaluable patients (49.8\%). As reported previously, elevated CTC counts were significantly associated with the extent of metastatic disease (i.e. more than one metastatic site $[p=0.030]$ and both visceral and bone involvement $[p=0.007])$ but not with other classical clinical-pathological factors (19). The HER2 status of CTCs was positive in 57 out of 180 patients (32\%) in whom at least one CTC was detected. $26 \%$ of patients with HER2negative primary tumor and/or metastasis had HER2-positive CTCs, compared to $45 \%$ of HER2-positive patients $(p=0.022)$. HER2 status of CTCs was not associated with other clinical-pathological factors. The distribution of patients is summarized in a REMARK diagram (Figure 1).

Serum HER2 detection. 119 of 251 (47\%) patients had sHER2 levels above the cut-off level of $15 \mathrm{ng} / \mathrm{ml}$. Patients with HER2positive primary tumor and/or metastasis were significantly more likely to present with elevated sHER 2 levels. $65 \%$ of tissue HER2-positive patients had elevated sHER2 levels in comparison with $38 \%$ of tissue HER2-negative patients 


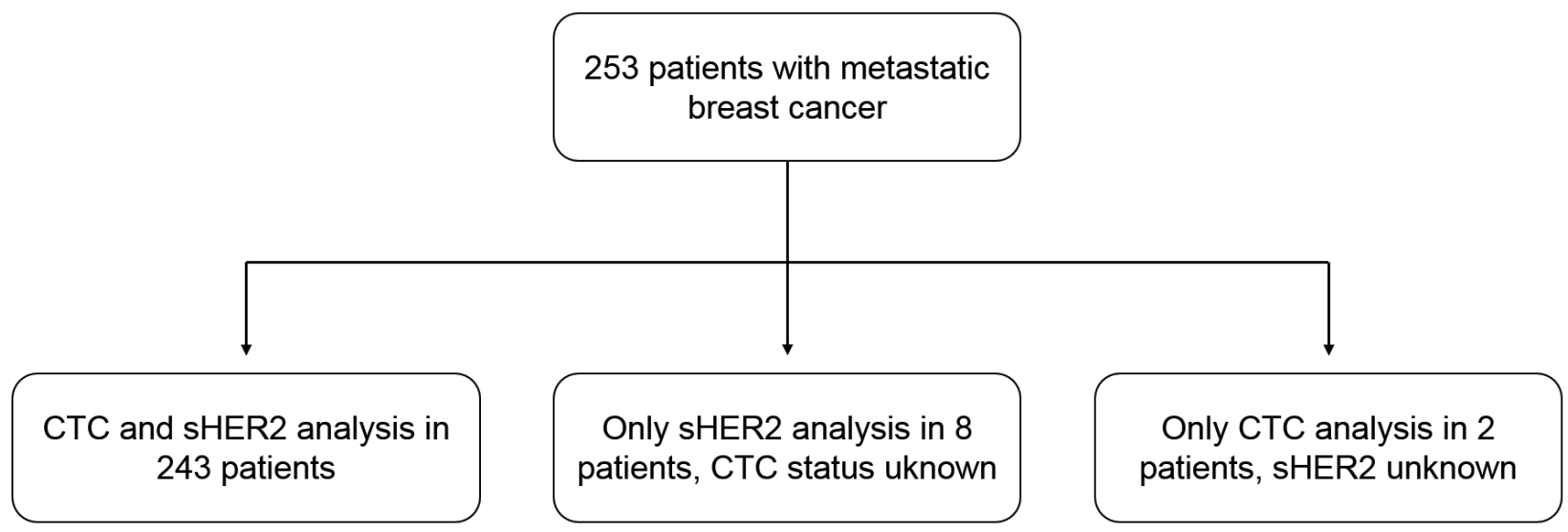

Figure 1. Patient distribution diagram according to the REMARK criteria.

$(p<0.001)$. Multiple metastatic sites $(p=0.004)$, visceral and bone involvement $(p=0.030)$ and positive HER2 status of CTCs $(p=0.035)$ were associated with higher sHER2 levels as well. Neither hormone receptor status nor line of therapy correlated with sHER2 levels (Table I). CTC-positive patients were more likely to present with elevated levels of sHER2: in patients with $\geq 5$ CTCs, serum levels were above the cut-off for sHER2 in $61 \% v s .33 \%$ in those with less than 5 CTCs per 7.5 $\mathrm{ml}$ of peripheral blood $(p<0.001)$.

Survival analysis. During a median follow up of 19 months, 85 patients deceased and 183 were diagnosed with progressive disease. Median progression-free survival (PFS) was 7.2 months (95\% CI=4.9-9.5 months) for patients with elevated sHER2 versus 8.7 months (7.0-10.5 months) with non-elevated levels $(p=0.06)$. Median overall survival (OS) was 16.3 months (95\% CI=10.0-22.6 months) in patients with elevated sHER2 levels; median OS in patients with non-elevated sHER2 has not been reached ( $p=0.001$ ) (Figure 2a). Presence of $\geq 5$ CTCs per $7.5 \mathrm{ml}$ blood was significantly associated with shorter PFS (5.7 [95\% CI=4.5-7.0] vs. 10.3 [8.4-12.2] months, $p=0.001$ ) and OS (median 12.6 [95\% CI=7.8-17.3] months vs. not reached, $p<0.001$ ) (Figure 2b). Patients with elevated sHER2 and $\geq 5$ CTCs had the shortest PFS (5.6 [95\%-CI=3.3-7.8] months) and OS (median 12.3 [95\% CI=5.3-19.3] months), compared to those with non-elevated sHER2 and <5 CTCs (PFS: $11.4[95 \%$ $\mathrm{CI}=8.7-12.2]$ months; median OS not reached) ( $p=0.04$ for PFS and $p<0.001$ for OS) (Figure 2c). In a multivariate analysis, presence of $\geq 5$ CTCs, higher grading and higher line of therapy remained independent predictors of shorter OS (Table II). Negative ER status, higher line of therapy and elevated CTC counts were independent predictors of shorter PFS in the multivariate analysis.
Table II. Multivariate analysis of overall survival.

\begin{tabular}{|c|c|c|c|}
\hline & $p$-Value & $\begin{array}{c}\text { Hazard } \\
\text { Ratio }\end{array}$ & $\begin{array}{c}95 \%- \\
\text { Confidence } \\
\text { Interval }\end{array}$ \\
\hline \multicolumn{4}{|l|}{ sHER2 } \\
\hline Elevated $v s$. non elevated & 0.063 & 1.702 & $0.97-2.98$ \\
\hline $\begin{array}{l}\text { Therapy line } \\
>1 \text { st line vs. 1st line }\end{array}$ & $<0.001$ & 3.105 & $1.65-5.84$ \\
\hline \multicolumn{4}{|l|}{ Menopausal status } \\
\hline Post- $v s$. Premenopausal & 0.446 & 0.807 & $0.47-1.40$ \\
\hline $\begin{array}{l}\text { ER status } \\
\text { Positive } v s \text {. Negative }\end{array}$ & 0.068 & 0.488 & $0.23-1.05$ \\
\hline \multicolumn{4}{|l|}{ PR status } \\
\hline \multicolumn{4}{|l|}{ HER2 status } \\
\hline Positive vs. Negative & 0.101 & 0.614 & $0.34-1.10$ \\
\hline \multicolumn{4}{|l|}{ Number of metastatic sites } \\
\hline $\begin{array}{l}\text { Multiple vs. Single site } \\
\text { CTC counts }\end{array}$ & 0.202 & 2.556 & $0.60-10.82$ \\
\hline$\geq 5$ vs. $<5$ CTCs $/ 7.5 \mathrm{ml}$ blood & $<0.001$ & 4.096 & $2.23-7.54$ \\
\hline
\end{tabular}

No significant association was found between the HER2 status of CTCs and overall $(p=0.492)$ or progression-free survival $(p=0.692)$.

Survival analysis in subgroups stratified by the HER2 status of the tumor. Separate survival analyses were conducted in tissue HER2-negative and tissue HER2-positive patients. In patients with HER2-negative tumors (Figure 3a), sHER2 was significantly associated with OS $(p=0.001)$ and PFS $(p=0.021)$. In this subgroup, the CTC status was a strong predictor of OS and PFS as well. 
Table III. Univariate survival analysis in the (a) HER2-positive and (b) HER2-negative subgroup.

(a)

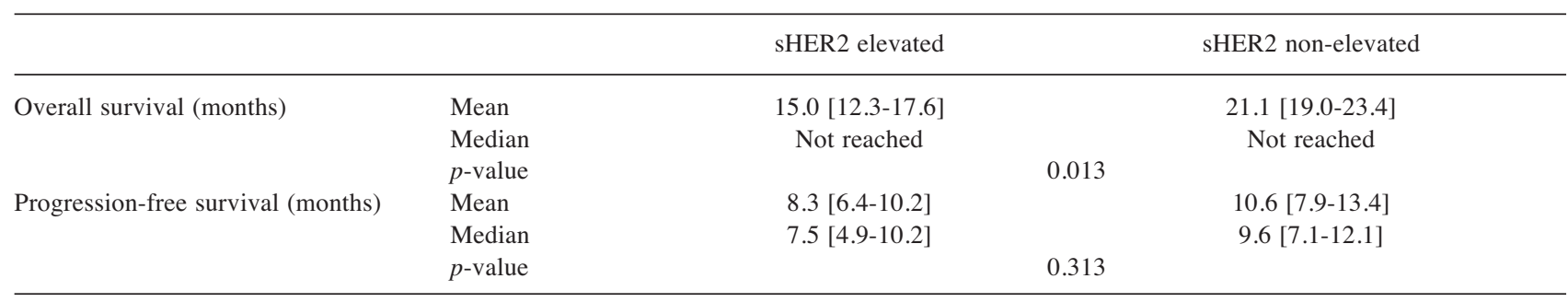

(b)

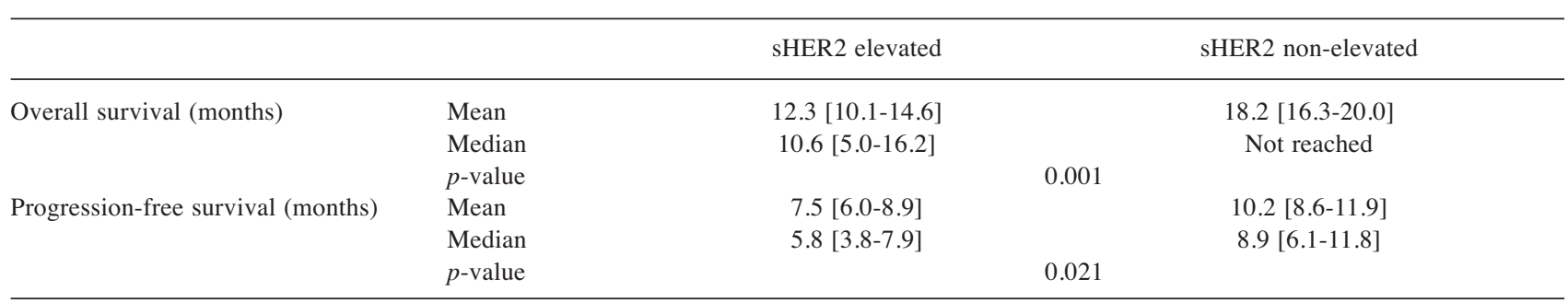

In patients with HER2-positive tumors, elevated sHER2 predicted shorter OS $(p=0.013)$ but not PFS $(p=0.313)$ (Figure $3 b$ ). The presence of $\geq 5$ CTCs correlated with shorter OS and PFS in these patients.

\section{Discussion}

In the current study, we aimed at evaluating the correlation between sHER2 levels and another promising biomarker, CTCs, and their impact on survival in a multicentre cohort of metastatic breast cancer patients.

The current body of evidence supporting CTCs as a strong independent prognostic factor is much larger than that regarding SHER2. The clinical relevance of CTC detection in early and advanced BC has been confirmed in two pooled analyses including 1944 non-metastatic and 3,173 metastatic patients $(20,21)$. Various molecular and immunocytological assays have been developed for CTC diagnostics, most of them based on the detection of epithelial markers, such as cytokeratins and EpCAM. Among those, the FDA approved CellSearch ${ }^{\circledR}$ system is the most widely used detection tool and has been employed in a number of clinical trials, such as the Southwest Oncology Group (SWOG) 0500, CirCe01 (Circulating Tumor Cells to Guide Chemotherapy for Metastatic Breast Cancer), STIC-CTC (Medico-economic Interest of Taking Into Account Circulating Tumor Cells to Determine the Kind of First Line Treatment for Metastatic, Hormone-receptors Positive, Breast Cancers), DETECT III (A Multicenter, Phase III Study to Compare Standard Therapy +/- Lapatinib in HER2-ve MBC-Patients With HER2+ve CTCs) and DETECT IV (A Study in Patients With HER2- negative Metastatic Breast Cancer and Persisting HER2negative Circulating Tumor Cells) (22). While the majority of studies conducted in the adjuvant setting considers patients CTC-positive if at least one tumor cell is detected, a cut-off of $\geq 5$ tumor cells per $7.5 \mathrm{ml}$ blood is currently being used as gold standard to identify patients with unfavorable prognosis in the metastatic situation (23).

Serum HER2 detection. Several approaches to measure the extracellular domain of HER2 in the serum have been introduced, most of them based on the ELISA method (2427). While a direct comparison of the results reported by early studies in the 1990s has been difficult due to the lack of standardization and the variety of cut-offs employed, most recent trials used the FDA-cleared ELISA test with the standardized cut-off of $15 \mathrm{ng} / \mathrm{ml}$ to distinguish between nonelevated and elevated sHER2 levels, determined as part of the data submitted to the FDA $(26,28,29)$ (Tables III and IV). Patients with HER2-overexpressing tumors are more likely to have elevated sHER2 than those with sHER2negative disease: in a meta-analysis including 1902 patients, median sHER2 levels before start of treatment were significantly higher in patients with HER2-positive tumors (25.1 ng/ml vs. $10.1 \mathrm{ng} / \mathrm{ml}$, respectively) (13). This is in accordance with the present study: we found elevated sHER2 levels in $65 \%$ of patients with HER2-positive tumors compared to $38 \%$ of those with HER2-negative disease.

The majority of studies on sHER2 in breast cancer have focussed on one of the following aspects: (A) the prognostic relevance of sHER2, (B) the feasibility of sHER2 for therapy monitoring and $(\mathrm{C})$ therapy selection based on sHER2. 
Prognostic relevance of $S H E R 2$ in breast cancer. The largest dataset on the prognostic significance of sHER2 in metastatic setting is the meta-analysis of three prospective randomized lapatinib-based trials (EGF30008, EGF30001 and EGF100151) (13). In these trials patients received standard chemo- (paclitaxel or capecitabine) or endocrine therapy $+/$ lapatinib. Patients with elevated sHER2 levels benefited most from lapatinib; this effect was independent of the HER 2 status of the tumor. In the control group, which did not receive HER2-targeted therapy, high baseline sHER2 was an independent predictor of shorter PFS and OS. Several large trials in metastatic setting showed a significant association between higher sHER2 and worse clinical outcome while others found no prognostic significance (Table III). In non-metastatic BC, numerous trials demonstrated that elevated sHER 2 levels at time of diagnosis predict poor clinical outcome (Table IV).

Furthermore, Fehm et al. analyzed blood samples from 152 initially non-metastatic BC and showed that sHER2 levels may change during the clinical course of disease (30). A significant proportion of sHER2-negative patients at time of diagnosis of early breast cancer turned sHER2-positive when diagnosed with metastatic disease. Interestingly, only few of the initially sHER2-positive patients became sHER2-negative. In this study sHER2 status at time of diagnosis of metastatic disease was associated with poor clinical outcome as well.

In our study, patients with elevated sHER2 levels had shorter overall survival, but sHER2 was no longer an independent prognostic factor when included into a multivariate regression analysis besides - among other factors - the CTC status. To our knowledge, this is the largest study examining both biomarkers in metastatic BC. Fehm et al. analyzed blood samples from 77 metastatic BC patients with negative or unknown HER2 status and determined sHER2 as well as the HER2 status of CTCs (31). 23 patients were HER2-positive using at least one method; the concordance between both techniques was $71 \%$. Another smaller study determined sHER2 and CTC status in 68 mostly HER2-negative metastatic BC patients (32). sHER2 did not affect clinical outcome but was associated with CTC number and the HER2 status of CTCs. In our study, we were able to confirm that CTC-positive patients were more likely to have elevated sHER 2 levels (61\% vs. $33 \%$ in CTCnegative patients, $p<0.001)$.

Serum HER2 and therapy monitoring. The possibility of assessing the current status of the disease is regarded as one of the most promising potentials of blood-based biomarkers. A simple and non-invasive blood test represents an attractive tool allowing real-time insight into the features and activity of the disease ("liquid biopsy"). With respect to CTCs, it has already been shown that CTC dynamics in metastatic BC predict response to therapy sooner than conventional
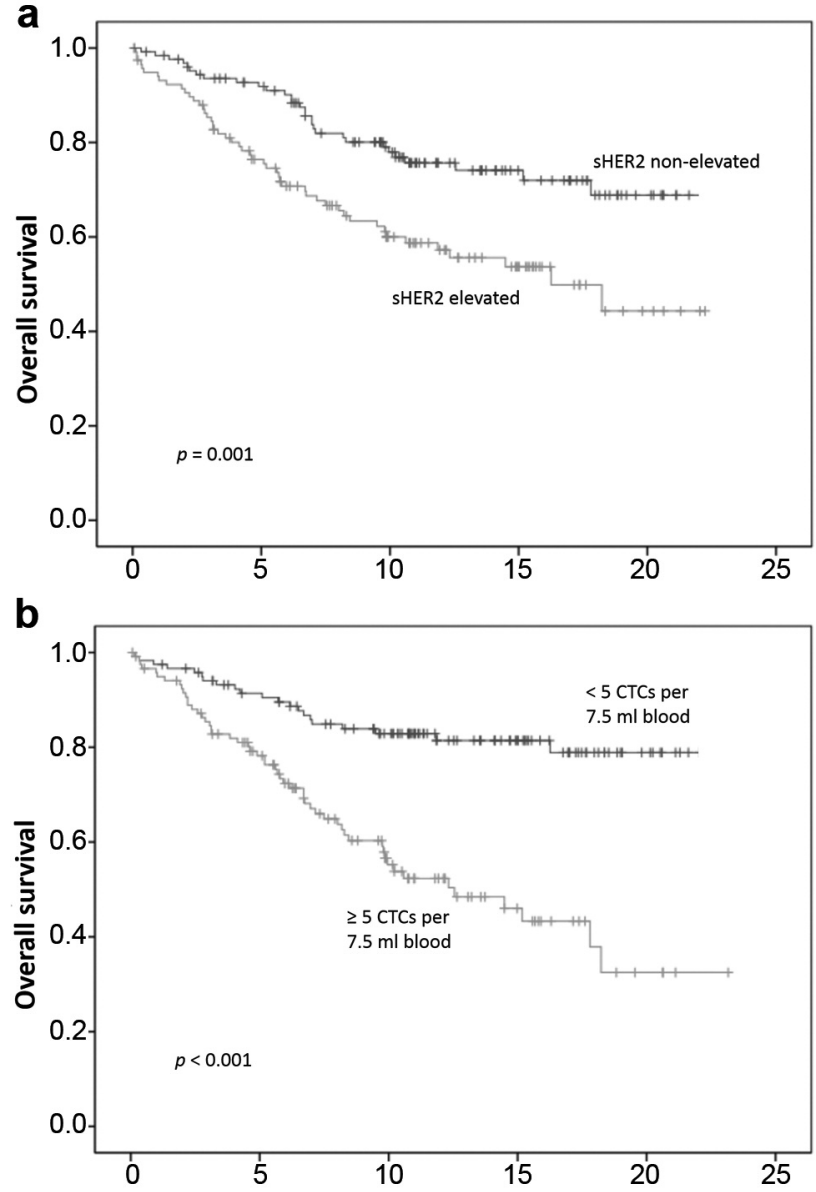

C

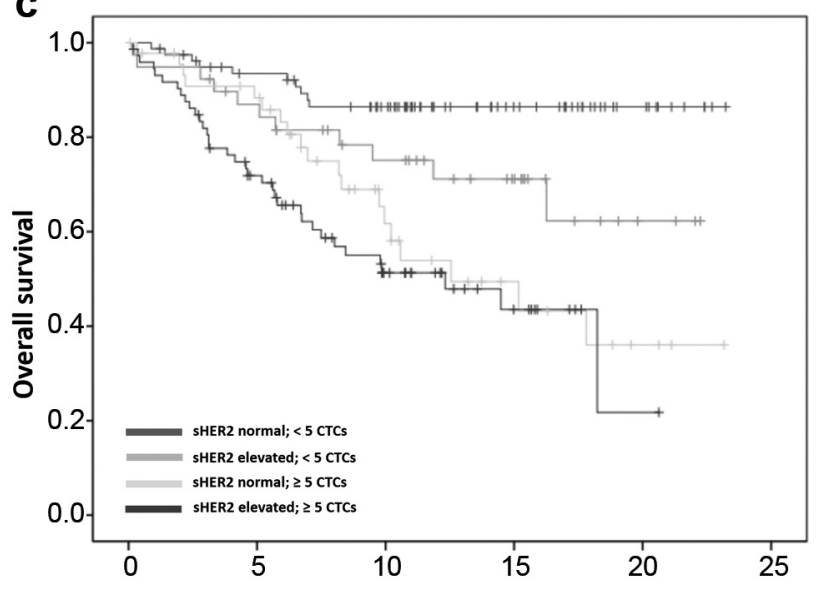

Figure 2. Correlation between overall survival [months] and a) serum HER2 levels; b) CTC counts; c) sHER2 and CTCs.

imaging-based evaluation and that clinical outcome is poorest in patients with persistently high CTC levels (33, 34). However, the optimal management of such patients has not yet been clarified (34). 

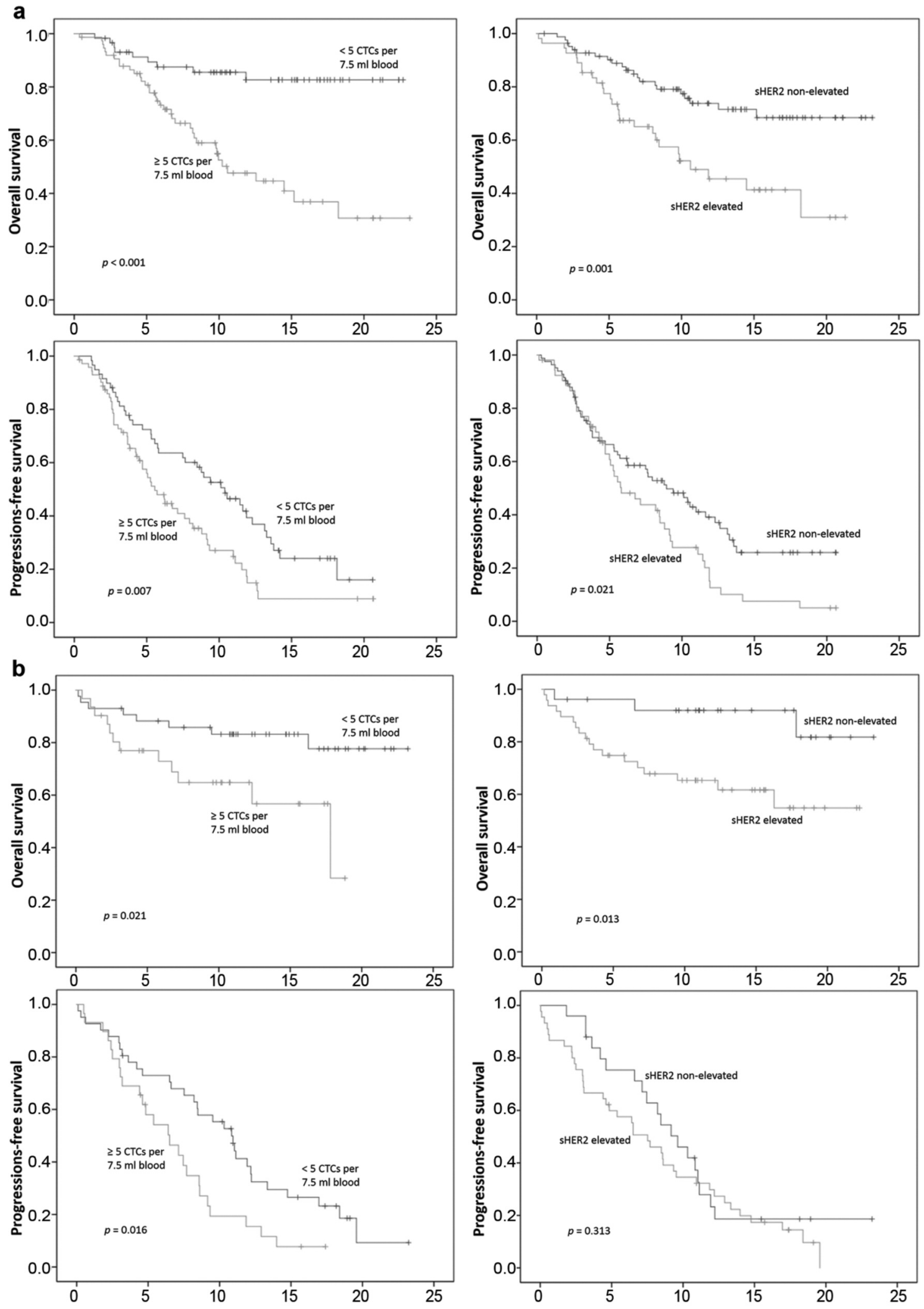

Figure 3. Kaplan-Meier overall and progression-free survival analysis in a) HER2 negative and b) HER2 positive patients according to sHER2 levels and CTC status [months]. 
Table IV. Current evidence regarding serum HER2 in metastatic breast cancer.

\begin{tabular}{|c|c|c|c|c|c|}
\hline Study & Setting & $\begin{array}{l}\text { Patients, } \\
\mathrm{n}\end{array}$ & Method & $\begin{array}{l}\text { Follow up } \\
\text { (months) }\end{array}$ & $\begin{array}{l}\text { Prognostic } \\
\text { significance }\end{array}$ \\
\hline Our study & $\begin{array}{c}\text { Metastatic } \\
\text { HER2-pos and neg }\end{array}$ & 251 & ELISA $^{1}$ & 19 & $\begin{array}{l}\text { Univariate: OS (irrespective of the HER2 status } \\
\text { of the tumor); PFS in HER2-negative patients } \\
\text { Multivariate: No }\end{array}$ \\
\hline $\begin{array}{l}\text { Lee } \text { et al. (13) } \\
\text { Meta-analysis } \\
\text { of EGF30008, } \\
\text { EGF30001 and } \\
\text { EGF100151 }\end{array}$ & $\begin{array}{c}\text { Metastatic } \\
\text { HER2-pos and neg }\end{array}$ & 1,902 & ELISA $^{1}$ & n.a. & $\begin{array}{c}\mathrm{PFS}^{3}, \mathrm{OS}^{3} \text { (in patients not treated } \\
\text { with HER2-targeted therapy) } \\
\text { Elevated sHER2 associated with higher } \\
\text { PFS benefit from lapatinib }\end{array}$ \\
\hline EGF30001 (35) & $\begin{array}{c}\text { Metastatic } \\
\text { HER2-neg or unknown }\end{array}$ & 579 & ELISA $^{5}$ & n.a. & $\begin{array}{c}\text { Baseline sHER2: none } \\
\text { Changes in sHER2 levels: PFS } 4\end{array}$ \\
\hline Lipton et al. (41) & $\begin{array}{l}\text { Metastatic } \\
\text { HER2-pos and neg }\end{array}$ & 562 & ELISA $^{1}$ & n.a. & $\mathrm{PFS}^{3}$ \\
\hline CALGB 8662 (24) & $\begin{array}{c}\text { Metastatic } \\
\text { HER2-pos and neg }\end{array}$ & 242 & $\begin{array}{l}\text { Sandwich enzyme } \\
\text { immunoassay }\end{array}$ & n.a. & $\begin{array}{l}\text { Univariate: OS } \\
\text { Multivariate: None }\end{array}$ \\
\hline Lipton et al. (42) & $\begin{array}{l}\text { Metastatic/Advanced }{ }^{2} \\
\text { HER2-pos and neg }\end{array}$ & 240 & ELISA $^{1}$ & n.a. & $\mathrm{OS}^{3}$ \\
\hline Fehm et al. (30) & $\begin{array}{c}\text { Metastatic } \\
\text { HER2-pos and neg }\end{array}$ & 152 & ELISA $^{1}$ & 35 & $\mathrm{OS}^{3}$ \\
\hline EGF20009 (43) & $\begin{array}{l}\text { Metastatic } \\
\text { HER2-pos }\end{array}$ & 138 & ELISA $^{1}$ & n.a. & $\begin{array}{c}\text { Baseline sHER2: none } \\
\text { Decline in sHER2 levels: } \text { PFS }^{3}\end{array}$ \\
\hline Esteva et al. (37) & $\begin{array}{l}\text { Metastatic } \\
\text { HER2-pos }\end{array}$ & 103 & ELISA $^{1}$ & 8 & $\begin{array}{c}\text { Baseline sHER2: none } \\
\text { Decline in sHER2 levels: } \text { PFS }^{4}\end{array}$ \\
\hline Aurilio et al. (32) & $\begin{array}{c}\text { Metastatic } \\
\text { HER2-pos and neg }\end{array}$ & 68 & ELISA $^{1}$ & n.a. & None \\
\hline Fornier et al. (38) & $\begin{array}{c}\text { Metastatic } \\
\text { HER2-pos and neg }\end{array}$ & 55 & ELISA $^{1}$ & n.a. & $\begin{array}{l}\text { Baseline sHER2: none } \\
\text { Decline in sHER2 levels: response to therapy } 4\end{array}$ \\
\hline Burstein et al. (44) & $\begin{array}{l}\text { Metastatic } \\
\text { HER2-pos }\end{array}$ & 54 & ELISA $^{1}$ & n.a. & Decline in sHER2 levels: PFS $^{4}$ \\
\hline Hayashi et al. (27) & $\begin{array}{c}\text { Metastatic } \\
\text { ER2-pos and neg }\end{array}$ & 52 & ELISA $^{6}$ & 22 & None \\
\hline Kong et al. (45) & $\begin{array}{l}\text { Metastatic } \\
\text { HER2-pos }\end{array}$ & 50 & ELISA $^{1}$ & n.a. & $\begin{array}{l}\text { Baseline sHER2: none } \\
\text { Decline in sHER2 levels: response to therapy }{ }^{4}\end{array}$ \\
\hline Reix et al. (9) & $\begin{array}{l}\text { Metastatic } \\
\text { HER2-pos }\end{array}$ & 48 & ELISA $^{1}$ & 68 & $\mathrm{PFS}^{3}, \mathrm{OS}^{3}$ \\
\hline
\end{tabular}

${ }^{1}$ Cut-off $15 \mathrm{ng} / \mathrm{ml} ;{ }^{2}$ measured at time of progression in patients with initially non-elevated sHER $2 ;{ }^{3}$ multivariate analysis; ${ }^{4}$ univariate analysis; ${ }^{5}$ cutoff $16 \mathrm{ng} / \mathrm{ml} ;{ }^{6}$ two methods with different cut-offs.

Numerous trials aimed at determining the usefulness of sHER2 for therapy monitoring in both metastatic and early BC setting (Tables III and IV). In the EGF30001 trial, 579 patients with newly diagnosed metastatic $\mathrm{BC}$ were randomized to receive paclitaxel with lapatinib or placebo (35). Blood samples were collected before start of first-line therapy and every 9-12 weeks thereafter. An additional analysis of sHER2 dynamics was performed in 391 patients with HER2-negative tumors. In patients with initially elevated sHER2 levels, conversion to non-elevated sHER2 during treatment predicted better PFS compared to those with persistently high sHER2. Conversely, patients whose sHER2 levels rose in the course of therapy had a worse PFS that those whose sHER2 levels remained low. Changes in sHER2 levels in patients with
HER2-positive tumors were analyzed in the EGF20009 trial (36). sHER2 was determined before start of first-line therapy with lapatinib and every four weeks thereafter in 138 metastatic BC patients. A decrease in sHER2 levels of at least $20 \%$ predicted better PFS; conversely, an increase of $\geq 20 \%$ was associated with worse PFS. Similar results were demonstrated in smaller studies as well $(37,38)$.

The feasibility of sHER2 analysis or therapy monitoring in non-metastatic BC has been evaluated in a number of trials (Table V). Reix et al. examined changes of sHER2 during neoadjuvant chemotherapy in $106 \mathrm{BC}$ patients and observed a significant decrease in sHER2 levels only in patients who achieved complete remission (9). This is in line with two German neoadjuvant trials: GeparQuattro and 
Table V. Current evidence regarding serum HER2 in non-metastatic breast cancer.

\begin{tabular}{|c|c|c|c|c|c|c|}
\hline Study & Setting & $\begin{array}{c}\text { Patients, } \\
\mathrm{n}\end{array}$ & Method & $\begin{array}{l}\text { Follow up } \\
\text { (months) }\end{array}$ & $\begin{array}{l}\text { Prognostic } \\
\text { significance }\end{array}$ & $\begin{array}{l}\text { Association } \\
\text { with pCR* }\end{array}$ \\
\hline NCCTG & Adjuvant & 2,318 & ELISA $^{1}$ & 56 & $\mathrm{DFS}^{4}$ & - \\
\hline N9831 (8) & Recurrent & 124 & & & $\mathrm{OS}^{4}$ & \\
\hline Lee et al. (46) & Adjuvant & 436 & ELISA $^{1}$ & 50 & $\mathrm{DFS}^{3}$ & - \\
\hline Reix et al. (9) & (Neo)Adjuvant & 286 & ELISA 1 & 68 & $\mathrm{DFS}^{4}, \mathrm{OS}^{3}$ & $\begin{array}{c}\text { Decline in sHER2 levels } \\
\text { observed only in pCR patients }\end{array}$ \\
\hline Ludovini et al. (47) & Adjuvant & 256 & ELISA $^{1}$ & 38 & $\mathrm{DFS}^{3}$ & - \\
\hline Fehm et al. (50) & Adjuvant & 211 & ELISA $^{5}$ & n.a. & $\mathrm{DFS}^{3}$ & - \\
\hline Witzel et al. (10) & Neoadjuvant & 210 & ELISA $^{1}$ & & & $\begin{array}{l}\text { Decline in sHER2 levels significantly } \\
\text { associated with pCR in patients } \\
\text { treated with lapatinib }\end{array}$ \\
\hline Ryu et al. (39) & Adjuvant & 200 & ELISA $^{1}$ & 38 & $\begin{array}{c}\text { Baseline sHER2: } \\
\text { DFS4, OS } 4 \\
\text { Decline in sHER2: OS } 4\end{array}$ & - \\
\hline Witzel et al. (12) & Neoadjuvant & 175 & ELISA $^{1}$ & & & $\begin{array}{l}\text { Decline in sHER2 levels and } \\
\text { initially elevated sHER } 2 \text { significantly } \\
\text { associated with pCR in patients } \\
\text { receiving HER2-targeted therapy }\end{array}$ \\
\hline Tchou et al. (48) & Adjuvant & 118 & MBB-ELISA ${ }^{2}$ & 21 & DFS $^{3}$ & - \\
\hline Thureau et al. (49) & Adjuvant & 65 & ELISA $^{1}$ & 53 & $\mathrm{DFS}^{3}, \mathrm{OS}^{3}$ & - \\
\hline
\end{tabular}

*In case of neoadjuvant study; ${ }^{1}$ cut-off $15 \mathrm{ng} / \mathrm{ml} ;{ }^{2}$ cut-off $7 \mathrm{ng} / \mathrm{ml} ;{ }^{3}$ multivariate analysis; ${ }^{4}$ univariate analysis; ${ }^{5}$ cut-off $120 \mathrm{fmol} / \mathrm{ml}$.

GeparQuinto. Witzel et al. analyzed the data from the translational project of the GeparQuinto trial and reported that a significant decrease of sHER2 levels predicted complete remission in a univariate analysis (10). In the multivariate analysis, the association of sHER2 decrease and pCR was significant only in patients receiving lapatinib but not trastuzumab. In contrast, the GeparQuattro trial confirmed sHER2 decline as an independent predictor in trastuzumab-treated patients (12). sHER2 dynamics have been explored in the adjuvant setting as well: Ryu et al. collected blood samples before and after adjuvant chemotherapy in 200 patients with non-metastatic BC patients (39). An increase in sHER2 levels during treatment predicted shorter DFS in a univariate analysis.

Therapy selection based on serum HER2. Treatment decisions are based on the histological characteristics of tumor tissue without considering features of minimal residual disease, although the latter is the aim of systemic therapy as well. With regard to HER2, Riethdorf et al. reported that in one-fifth of patients with HER2-negative BC HER2-positive CTCs may be detected (14). However, these patients are not eligible for anti-HER2 targeted treatment. In our study, elevated sHER2 levels were detected in $38 \%$ of patients with HER2-negative tumors. In this patient group, sHER2 was significantly associated with OS and PFS. It remains unclear, whether these patients might benefit from anti-HER2 directed therapy. Interestingly, in the meta-analysis by Lee et al., patients with high sHER2 levels benefited from lapatinib therapy regardless of the HER2 status of the tumor (13). It has also been shown that HER2-targeted agents can eliminate HER2-positive CTCs in metastatic BC irrespectively of the HER2 status of the primary tumor (40). The question whether the choice of systemic treatment might be driven by blood-based biomarkers, is currently being clarified in the DETECT trials (2).

\section{Conclusion}

The present study is the first large analysis of serum HER2 and CTCs in metastatic breast cancer patients. Our results confirm the previously reported association between elevated sHER2 levels and poor clinical outcome both in HER2negative and HER2-positive patients. However, determining sHER2 status does not provide additional prognostic information when CTC status is available.

\section{Trial Registration}

Current Controlled Trials ISRCTN59722891 (DETECT).

\section{Conflicts of Interest}

The Authors declare that they have no conflicts of interest. 


\section{Acknowledgements}

This work was supported by a research grant from Roche Pharma AG, Germany. Furthermore, this study was partly supported by Adnagen AG (Langenhagen, Germany). ELISA kits were provided at no cost by Oncogene Science, a former part of Siemens Medical Solutions Diagnostics and now part of Wilex.

\section{References}

1 Pantel K and Brakenhoff RH: Dissecting the metastatic cascade. Nat Rev Cancer 4: 448-456, 2004.

2 Banys-Paluchowski M, Krawczyk N, Meier-Stiegen F and Fehm T: Circulating tumor cells in breast cancer - current status and perspectives. Crit Rev Oncol Hematol 97: 22-29, 2016.

3 Cristofanilli M, Hayes DF, Budd GT, Ellis MJ, Stopeck A, Reuben JM, Doyle GV, Matera J, Allard WJ, Miller MC, Fritsche HA, Hortobagyi GN and Terstappen LW: Circulating tumor cells: a novel prognostic factor for newly diagnosed metastatic breast cancer. J Clin Oncol 23: 1420-1430, 2005.

4 Hartkopf AD, Banys M, Meier-Stiegen F, Hahn M, Rohm C, Hoffmann J, Helms G, Taran FA, Wallwiener M, Walter C, Neubauer H, Wallwiener D and Fehm T: The HER2 status of disseminated tumor cells in the bone marrow of early breast cancer patients is independent from primary tumor and predicts higher risk of relapse. Breast Cancer Res Treat 138: 509-517, 2013.

5 Krawczyk N, Banys M, Neubauer H, Solomayer EF, Gall C, Hahn M, Becker S, Bachmann R, Wallwiener D and Fehm T: HER2 status on persistent disseminated tumor cells after adjuvant therapy may differ from initial HER2 status on primary tumor. Anticancer Res 29: 4019-4024, 2009.

6 Fehm T, Muller V, Aktas B, Janni W, Schneeweiss A, Stickeler E, Lattrich C, Lohberg CR, Solomayer E, Rack B, Riethdorf S, Klein C, Schindlbeck C, Brocker K, Kasimir-Bauer S, Wallwiener D and Pantel K: HER2 status of circulating tumor cells in patients with metastatic breast cancer: a prospective, multicenter trial. Breast Cancer Res Treat 124: 403-412, 2010.

7 Lee SB, Lee JW, Yu JH, Ko BS, Kim HJ, Son BH, Gong G, Lee HJ, Kim SB, Jung KH, Ahn JH, Lee W, Sung J and Ahn SH: Preoperative serum HER2 extracellular domain levels in primary invasive breast cancer. BMC Cancer 14: 929, 2014.

8 Moreno-Aspitia A, Hillman DW, Dyar SH, Tenner KS, Gralow J, Kaufman PA, Davidson NE, Lafky JM, Reinholz MM, Lingle WL, Kutteh LA, Carney WP, Dueck AC and Perez EA: Soluble human epidermal growth factor receptor 2 (HER2) levels in patients with HER2-positive breast cancer receiving chemotherapy with or without trastuzumab: results from North Central Cancer Treatment Group adjuvant trial N9831. Cancer 119: 2675-2682, 2013.

9 Reix N, Malina C, Chenard MP, Bellocq JP, Delpous S, Moliere $\mathrm{S}$, Sevrin A, Neuberger K, Tomasetto C and Mathelin C: A prospective study to assess the clinical utility of serum HER2 extracellular domain in breast cancer with HER2 overexpression. Breast Cancer Res Treat 160: 249-259, 2016.

10 Witzel I, Loibl S, von Minckwitz G, Eidtmann H, Fehm T, Khandan F, Schmatloch S, Hauschild M, Bischoff J, Fasching PA, Mau C, Schem C, Rack B, Meinhold-Heerlein I, Liedtke C, Karn T, Huober J, Zu Eulenburg C, Issa-Nummer Y, Untch M and Muller V: Predictive value of HER2 serum levels in patients treated with lapatinib or trastuzumab - a translational project in the neoadjuvant GeparQuinto trial. Br J Cancer 107: 956-960, 2012.
11 Muller V, Witzel I, Luck HJ, Kohler G, von Minckwitz G, Mobus V, Sattler D, Wilczak W, Loning T, Janicke F, Pantel K and Thomssen C: Prognostic and predictive impact of the HER2/ neu extracellular domain (ECD) in the serum of patients treated with chemotherapy for metastatic breast cancer. Breast Cancer Res Treat 86: 9-18, 2004.

12 Witzel I, Loibl S, von Minckwitz G, Mundhenke C, Huober J, Hanusch C, Henschen S, Hauschild M, Lantzsch T, Tesch H, Latos K, Just M, Hilfrich J, Barinoff J, Eulenburg CZ, Roller M, Untch M and Muller V: Monitoring serum HER2 levels during neoadjuvant trastuzumab treatment within the GeparQuattro trial. Breast Cancer Res Treat 123: 437-445, 2010.

13 Lee CK, Davies L, Gebski VJ, Lord SJ, Di Leo A, Johnston S, Geyer C, Jr., Cameron D, Press MF, Ellis C, Loi S, Marschner I, Simes J and de Souza P: Serum Human Epidermal Growth Factor 2 Extracellular Domain as a Predictive Biomarker for Lapatinib Treatment Efficacy in Patients With Advanced Breast Cancer. J Clin Oncol 34: 936-944, 2016.

14 Riethdorf S, Muller V, Zhang L, Rau T, Loibl S, Komor M, Roller M, Huober J, Fehm T, Schrader I, Hilfrich J, Holms F, Tesch H, Eidtmann H, Untch M, von Minckwitz G and Pantel K: Detection and HER2 expression of circulating tumor cells: prospective monitoring in breast cancer patients treated in the neoadjuvant GeparQuattro trial. Clin Cancer Res 16: 2634-2645, 2010.

15 Cook GB, Neaman IE, Goldblatt JL, Cambetas DR, Hussain M, Luftner D, Yeung KK, Chan DW, Schwartz MK and Allard WJ: Clinical utility of serum HER-2/neu testing on the Bayer Immuno 1 automated system in breast cancer. Anticancer Res 21: 1465-1470, 2001.

16 Schwartz MK, Smith C, Schwartz DC, Dnistrian A and Neiman I: Monitoring therapy by serum HER-2/neu. Int J Biol Markers 15: 324-329, 2000.

17 Carney WP, Neumann R, Lipton A, Leitzel K, Ali S and Price CP: Monitoring the circulating levels of the HER2/neu oncoprotein in breast cancer. Clin Breast Cancer 5: 105-116, 2004.

18 McShane LM, Altman DG, Sauerbrei W, Taube SE, Gion M and Clark GM: REporting recommendations for tumour MARKer prognostic studies (REMARK). Br J Cancer 93: 387-391, 2005.

19 Muller V, Riethdorf S, Rack B, Janni W, Fasching PA, Solomayer E, Aktas B, Kasimir-Bauer S, Zeitz J, Pantel K and Fehm T: Prospective evaluation of serum tissue inhibitor of metalloproteinase 1 and carbonic anhydrase IX in correlation to circulating tumor cells in patients with metastatic breast cancer. Breast Cancer Res 13: R71, 2011.

20 Bidard FC, Peeters DJ, Fehm T, Nole F, Gisbert-Criado R, Mavroudis D, Grisanti S, Generali D, Garcia-Saenz JA, Stebbing J, Caldas C, Gazzaniga P, Manso L, Zamarchi R, de Lascoiti AF, De Mattos-Arruda L, Ignatiadis M, Lebofsky R, van Laere SJ, MeierStiegen F, Sandri MT, Vidal-Martinez J, Politaki E, Consoli F, Bottini A, Diaz-Rubio E, Krell J, Dawson SJ, Raimondi C, Rutten A, Janni W, Munzone E, Caranana V, Agelaki S, Almici C, Dirix L, Solomayer EF, Zorzino L, Johannes H, Reis-Filho JS, Pantel K, Pierga JY and Michiels S: Clinical validity of circulating tumour cells in patients with metastatic breast cancer: a pooled analysis of individual patient data. Lancet Oncol 15: 406-414, 2014.

21 Janni WJ, Rack B, Terstappen LW, Pierga JY, Taran FA, Fehm T, Hall C, de Groot MR, Bidard FC, Friedl TW, Fasching PA, Brucker SY, Pantel K and Lucci A: Pooled Analysis of the Prognostic Relevance of Circulating Tumor Cells in Primary Breast Cancer. Clin Cancer Res 22: 2583-2593, 2016. 
22 Banys-Paluchowski M, Krawczyk N and Fehm T: Potential Role of Circulating Tumor Cell Detection and Monitoring in Breast Cancer: A Review of Current Evidence. Front Oncol 6: 255, 2016.

23 Cristofanilli M, Budd GT, Ellis MJ, Stopeck A, Matera J, Miller MC, Reuben JM, Doyle GV, Allard WJ, Terstappen LW and Hayes DF: Circulating tumor cells, disease progression, and survival in metastatic breast cancer. N Engl J Med 351: 781-791, 2004.

24 Hayes DF, Yamauchi H, Broadwater G, Cirrincione CT, Rodrigue SP, Berry DA, Younger J, Panasci LL, Millard F, Duggan DB, Norton L, Henderson IC, Cancer and Leukemia Group B: Circulating HER-2/erbB-2/c-neu (HER-2) extracellular domain as a prognostic factor in patients with metastatic breast cancer: Cancer and Leukemia Group B Study 8662. Clin Cancer Res 7: 2703-2711, 2001.

25 Tan LD, Xu YY, Yu Y, Li XQ, Chen Y and Feng YM: Serum HER2 level measured by dot blot: a valid and inexpensive assay for monitoring breast cancer progression. PLoS One 6: e18764, 2011.

26 Carney WP, Neumann R, Lipton A, Leitzel K, Ali S and Price CP: Potential clinical utility of serum HER-2/neu oncoprotein concentrations in patients with breast cancer. Clin Chem 49: 1579-1598, 2003.

27 Hayashi N, Nakamura S, Tokuda Y, Yagata H, Yoshida A, Ota H, Hortobagyi GN, Cristofanilli M and Ueno NT: Serum HER2 levels determined by two methods in patients with metastatic breast cancer. Int J Clin Oncol 17: 55-62, 2012.

28 Lam L, McAndrew N, Yee M, Fu T, Tchou JC and Zhang H: Challenges in the clinical utility of the serum test for HER2 ECD. Biochim Biophys Acta 1826: 199-208, 2012.

29 Carney WP, Leitzel K, Ali S, Neumann R and Lipton A: HER2/neu diagnostics in breast cancer. Breast Cancer Res 9: 207, 2007.

30 Fehm T, Jager W, Kraemer S, Sohn C, Solomayer-Meyberg G, Solomayer EF, Kurek R, Wallwiener D and Gebauer G: Changes of serum HER2 status during clinical course of metastatic breast cancer patients. Anticancer Res 24: 4205-4210, 2004.

31 Fehm T, Becker S, Duerr-Stoerzer S, Sotlar K, Mueller V, Wallwiener D, Lane N, Solomayer E and Uhr J: Determination of HER2 status using both serum HER2 levels and circulating tumor cells in patients with recurrent breast cancer whose primary tumor was HER2 negative or of unknown HER2 status. Breast Cancer Res 9: R74, 2007.

32 Aurilio G, Sandri MT, Pruneri G, Zorzino L, Botteri E, Munzone E, Adamoli L, Facchi G, Cullura D, Verri E, Rocca MC, Zurrida S, Iacovelli $\mathrm{R}$ and Nole F: Serum HER2 extracellular domain levels and HER2 circulating tumor cell status in patients with metastatic breast cancer. Future Oncol 12: 2001-2008, 2016.

33 Budd GT, Cristofanilli M, Ellis MJ, Stopeck A, Borden E, Miller MC, Matera J, Repollet M, Doyle GV, Terstappen LW and Hayes DF: Circulating tumor cells versus imaging - predicting overall survival in metastatic breast cancer. Clin Cancer Res 12: 64036409, 2006.

34 Smerage JB, Barlow WE, Hortobagyi GN, Winer EP, LeylandJones B, Srkalovic G, Tejwani S, Schott AF, O'Rourke MA, Lew DL, Doyle GV, Gralow JR, Livingston RB and Hayes DF: Circulating tumor cells and response to chemotherapy in metastatic breast cancer: SWOG S0500. J Clin Oncol 32: 3483$3489,2014$.

35 Finn RS, Gagnon R, Di Leo A, Press MF, Arbushites M and Koehler M: Prognostic and predictive value of HER2 extracellular domain in metastatic breast cancer treated with lapatinib and paclitaxel in a randomized phase III study. J Clin Oncol 27: 5552-5558, 2009.

36 Lipton A, Leitzel K, Ali SM, Carney W, Platek G, Steplewski K, Westlund R, Gagnon R, Martin AM and Maltzman J: Human epidermal growth factor receptor 2 (HER2) extracellular domain levels are associated with progression-free survival in patients with HER2-positive metastatic breast cancer receiving lapatinib monotherapy. Cancer 117: 5013-5020, 2011.

37 Esteva FJ, Cheli CD, Fritsche H, Fornier M, Slamon D, Thiel RP, Luftner D and Ghani F: Clinical utility of serum HER2/neu in monitoring and prediction of progression-free survival in metastatic breast cancer patients treated with trastuzumab-based therapies. Breast Cancer Res 7: R436-443, 2005.

38 Fornier MN, Seidman AD, Schwartz MK, Ghani F, Thiel R, Norton L and Hudis C: Serum HER2 extracellular domain in metastatic breast cancer patients treated with weekly trastuzumab and paclitaxel: association with HER2 status by immunohistochemistry and fluorescence in situ hybridization and with response rate. Ann Oncol 16: 234-239, 2005.

39 Ryu DW and Lee CH: Impact of Serum HER2 Levels on Survival and Its Correlation with Clinicopathological Parameters in Women with Breast Cancer. J Breast Cancer 15: 71-78, 2012.

40 Agelaki S, Kalykaki A, Markomanolaki H, Papadaki MA, Kallergi G, Hatzidaki D, Kalbakis K, Mavroudis D and Georgoulias V: Efficacy of Lapatinib in Therapy-Resistant HER2-Positive Circulating Tumor Cells in Metastatic Breast Cancer. PloS one 10: e0123683, 2015.

41 Lipton A, Ali SM, Leitzel K, Demers L, Harvey HA, ChaudriRoss HA, Brady C, Wyld P and Carney W: Serum HER-2/neu and response to the aromatase inhibitor letrozole versus tamoxifen. J Clin Oncol 21: 1967-1972, 2003.

42 Lipton A, Leitzel K, Ali SM, Demers L, Harvey HA, ChaudriRoss HA, Evans D, Lang R, Hackl W, Hamer P and Carney W: Serum HER-2/neu conversion to positive at the time of disease progression in patients with breast carcinoma on hormone therapy. Cancer 104: 257-263, 2005.

43 Lipton A, Leitzel K, Ali SM, Carney W, Platek G, Steplewski K, Westlund R, Gagnon R, Martin AM and Maltzman J: Human epidermal growth factor receptor 2 (HER2) extracellular domain levels are associated with progression-free survival in patients with HER2-positive metastatic breast cancer receiving lapatinib monotherapy. Cancer 117: 5013-5020, 2011

44 Burstein HJ, Harris LN, Marcom PK, Lambert-Falls R, Havlin K, Overmoyer B, Friedlander RJ, Jr., Gargiulo J, Strenger R, Vogel CL, Ryan PD, Ellis MJ, Nunes RA, Bunnell CA, Campos SM, Hallor M, Gelman R and Winer EP: Trastuzumab and vinorelbine as first-line therapy for HER2-overexpressing metastatic breast cancer: multicenter phase II trial with clinical outcomes, analysis of serum tumor markers as predictive factors, and cardiac surveillance algorithm. J Clin Oncol 21: 2889-2895, 2003.

45 Kong SY, Lee DH, Lee ES, Park S, Lee KS and Ro J: Serum HER2 as a response indicator to various chemotherapeutic agents in tissue HER2 positive metastatic breast cancer. Cancer Res Treat 38: 35-39, 2006.

46 Lee MH, Jung SY, Kang SH, Song EJ, Park IH, Kong SY, Kwon YM, Lee KS, Kang HS and Lee ES: The Significance of Serum HER2 Levels at Diagnosis on Intrinsic Subtype-Specific Outcome of Operable Breast Cancer Patients. PLoS One 11: e0163370, 2016 
47 Ludovini V, Gori S, Colozza M, Pistola L, Rulli E, Floriani I, Pacifico E, Tofanetti FR, Sidoni A, Basurto C, Rulli A and Crino L: Evaluation of serum HER2 extracellular domain in early breast cancer patients: correlation with clinicopathological parameters and survival. Ann Oncol 19: 883-890, 2008.

48 Tchou J, Lam L, Li YR, Edwards C, Ky B and Zhang H: Monitoring serum HER2 levels in breast cancer patients. Springerplus 4: 237, 2015.

49 Thureau S, Clatot F, Laberge-Le-Couteulx S, Baron M, Basuyau JP and Blot E: Elevated HER2 extracellular domain level in primary breast cancer with HER2 overexpression predicts early failure of adjuvant trastuzumab. Anticancer Res 32: 1429-1433, 2012.
50 Fehm T, Maimonis P, Weitz S, Teramoto Y, Katalinic A and Jäger W: Influence of circulating c-erbB-2 serum protein on response to adjuvant chemotherapy in node-positive breast cancer patients. Breast Cancer Res Treat 43: 87-95, 1997.

Received May 1, 2017

Revised May 11, 2017

Accepted May 15, 2017 